\title{
Thermal and crack resistance of ceramics based on the MAX phase $\mathrm{Ti}_{3} \mathrm{AlC}_{2}$
}

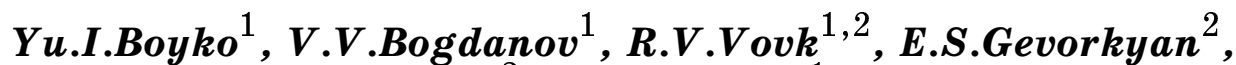 \\ V.A.Kolesnichenko ${ }^{3}$, V.F.Korshak ${ }^{1}$, T.A.Prikhna $^{4}$ \\ ${ }^{1}$ V.Karazin Kharkiv National University, \\ 4 Svobody Sq., 61022 Kharkiv, Ukraine \\ ${ }^{2}$ Ukrainian State University of Railway Transport, \\ 7 Feuerbach Sq., 61050 Kharkiv, Ukraine \\ ${ }^{3}$ M.Sytenko Institute of Spine and Joint Pathology, National Academy of \\ Medical Sciences of Ukraine, 80 Pushkinska Str., 61024 Kharkiv, Ukraine \\ ${ }^{4}$ V.Bakul Institute for Superhard Materials, \\ 2 Avtozavodskaya Str., 04074 Kyiv, Ukraine
}

Received Septebber 11, 2018

\begin{abstract}
The paper discusses the conditionality of such physical properties of polycomponent oxygen-free ceramics (MAX phases), as thermal and fracture resistance, with a special physicochemical nature of the binding forces between the elements forming the MAX phase and with a specific structural state characterized by the presence of thin interlayer between the structure elements with an unordered arrangement of atoms. The results of the experimental study of some of the physical properties of $\mathrm{Ti}_{3} \mathrm{AlC}_{2}$-based materials are presented, which are consistent with the proposed concept.
\end{abstract}

Keywords: MAX phases, heat resistance, crack resistance.

Обсуждается обусловленность таких физических свойств поликомпонентной бескислородной керамики (MAX-фаз), как термо- и трещиностойкость, особой физико-химической природой сил связи между элементами, формирующими МАХ фазу, и специфическим структурным состоянием, характеризующимся наличием тонких прослоек между элементами структуры с неупорядоченным расположением атомов. Приведены результаты экспериментального исследования некоторых физических свойств материалов на основе соединения $\mathrm{Ti}_{3} \mathrm{AlC}_{2}$, которые согласуются с предлагаемой концепцией.

Термо- і тріщиностійкість кераміки на основі МАХ-фази $\mathrm{Ti}_{3} \mathrm{AlC}_{2}$. Ю.І.Бойко, В.В.Богданов, Р.В.Вовк, Е.С.Геворкян, В.А.Колесніченко, В.Ф.Коршак, Т.А.Пріхна.

Обговорюється обумовленість таких фізичних властивостей полікомпонентної безкисневої кераміки (МАХ-фаз), як термо- і тріщиностійкість, особливою фізикохімічною природою сил зв'язку між елементами, що формують МАX фазу, і специфічним структурним станом, що характеризується наявністю тонких прошарків між елементами структури 3 неупорядкованим розташуванням атомів. Наведено результати експериментального дослідження деяких фізичних властивостей матеріалів на основі сполуки $\mathrm{Ti}_{3} \mathrm{AlC}_{2}$, які узгоджуються із запропонованою концепцією.

\section{Introduction}

It is known that polycomponent ceramic has unique physical properties and is an im- portant functional material, which is widely used in various industries. Recently, special attention in terms of practical application has been paid to ceramics on the basis of 
the so-called MAX phases. MAX phases are a kind of triple compounds with variable stoichiometry: $\mathrm{M}_{n+1} \mathrm{AX}_{n} \quad(n=1,2,3 \ldots)$, where $\mathrm{M}-3 d$ transition metal, $\mathrm{A}-p$-element (for example: $\mathrm{Al}, \mathrm{Ge}, \mathrm{Si}$ and etc.), $\mathrm{X}-$ carbon (C) or nitrogen (N) [1-4]. Of the large number of MAX phases synthesized to date, the most known and requiered are the phases based on titanium: $\mathrm{Ti}_{3} \mathrm{AlC}_{2}, \mathrm{Ti}_{2} \mathrm{AIN}$, $\mathrm{Ti}_{3} \mathrm{SiC}_{2}$ and etc. The main physical properties of these compounds, which determine their structural attractiveness, are thermal stability, as well as unique mechanical properties: on the one hand, these materials are characterized by a relatively high plasticity, and on the other hand they have great mechanical strength (considerable crack resistance up to failure).

In this paper, we discuss the factor of the special physico-chemical nature of the binding forces between atoms, which determines the unique properties of MAX phases, and also results of experimental research of some physical properties of these phases on the example of $\mathrm{Ti}_{3} \mathrm{AlC}_{2}$ compound, which are consistent with the proposed concept.

\section{Thermal resistance of $M A X$ phases}

It is obvious that in order to ensure the thermal stability of a polycomponent ceramics based on the MAX phase, it is necessary to use such components that, during the chemical reaction, when combined in the sintering process, form refractory compounds. The formation of such compounds provides not only an increased thermal stability of the material, but also causes an increase in the activation energy of atoms diffusion, which, in turn, leads to decrease in the rate of plastic deformation of the material at room and higher temperatures.

It is known that carbon is the most stable chemical element with respect to temperature (C). Under certain conditions, it is characterized by thermal stability up to $\approx 3500^{\circ} \mathrm{C}$ [5]. In the process of producing a ceramic material of the MAX phase on the basis of titanium and carbon, the intermediate phase is titanium carbide (TiC). For the melting point of titanium carbide in different sources, the values are $3127-3227^{\circ} \mathrm{C}$, which ultimately provides increased thermal stability of the MAX phase based on the elements $\mathrm{Ti}, \mathrm{Al}$, and $\mathrm{C}$. Let's pay attention to the fact that the thermal stability of carbon (C) and, respectively, of titanium carbide $(\mathrm{TiC})$ is significantly reduced in a medium containing oxygen (O). In order to prevent this negative effect of oxygen on the heat resistance of carbon and its compounds, silicon (Si) can be used as an additive [5].

Another refractory compound, possible candidate as a component in the production of ceramics with increased thermal stability on the basis of MAX phases, can be titanium nitride (TiN). The melting point of titanium nitride is $2950^{\circ} \mathrm{C}$, which can provide increased thermal stability of the MAX phase material using nitrogen $(\mathrm{N})$. It is necessary to pay special attention to the fact that the considered elements of Ti, Al, C and $\mathrm{N}$ in compounds with each other can change their valence [6]. In this case, the forming compounds are characterized by the formation of both an isotropic (metallic) bond and directed chemical bonds between the atoms (covalent or ionic). The presence of directed chemical bonds leads to an increase in the activation energy of atoms diffusion, which causes a decrease in the rate of plastic deformation at room and higher temperatures.

\section{Crack resistance of ceramics based on $M A X$ phases}

It is known that high fragility of materials (the tendency to cracking under the influence of mechanical stress, leading ultimately to the destruction of the material), including ceramics, is associated with their crystal-chemical structure, that is with the nature of the chemical bonds acting between different atoms and also with the presence or absence of long-range order in their arrangement. The crack opening occurs, as a rule, along the so-called "cleavage planes", which are characteristic for non-directional chemical bonds. Any deviation or violation of the degree of atoms ordering contributes to an increase in the fracture toughness of the material. For example, a completely disordered (amorphous) structure is characterized by the greatest crack resistance. The violation of ordering in the atoms arrangement is realized in the case when, firstly, the bond between atoms is directional (ionic or covalent) and, secondly, when the interacting atoms in the process of forming the polycomponent material can form a differ number of bonds [7].

As already mentioned, the atoms of titanium, carbon and nitrogen interact with a tendency to form directed chemical bonds, which promotes the formation of thermoand crack-resistant compounds. In addition, the above elements can easily change their valency $[5,6]$. Consequently, it is these ele- 


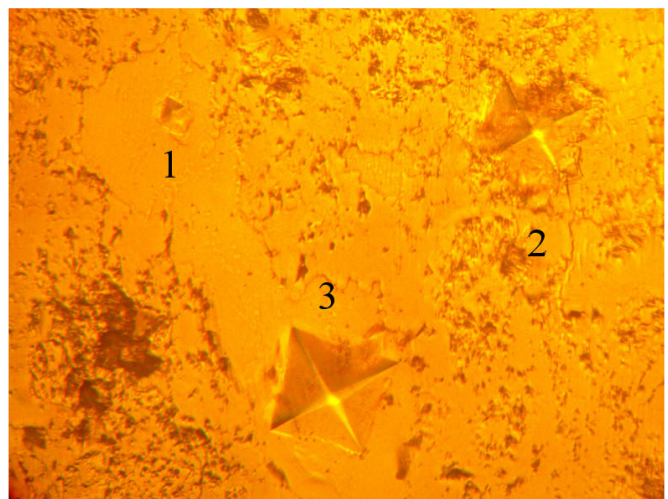

a)

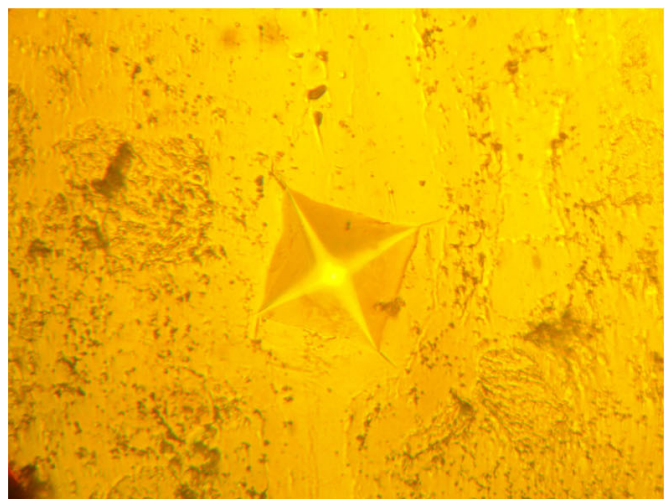

b)

Fig. 1. a - Imprints of the Vickers indentor at various loads: $1-P \approx 0.2 \mathrm{H} ; 2,3-P \approx 5 \mathrm{H}$ in different places of the sample; $\mathrm{b}$ - formation of microcracks near the corners of the imprint at the load $P \approx 7.4 \mathrm{H}$.

ments, combining in the process of chemical reactions when form the materials based on MAX-phases, can form structures, characterized by deviation from the orderly of atoms arrangement, and, as a result, have an increased crack resistance [7,8].

It should be noted that formation of MAX phase $\mathrm{Ti}_{3} \mathrm{AlC}_{2}$ in the temperature range $1350-1500^{\circ} \mathrm{C}$ occurs in stages. In the first stage, titanium reacts with carbon and aluminum, forming a refractory compound titanium carbide (TiC) and the liquid phase (Ti-Al). With further cooling during the formation of the MAX phase the crystalline TiC grains are surrounded by thin interlayers (boundaries) from the (Ti-Al)based phase, which are characterized by an unordered atoms arrangement.

To summarize, it can be argued that titanium $(\mathrm{Ti})$, carbon $(\mathrm{C})$, silicon $(\mathrm{Si})$, and nitrogen $(\mathrm{N})$ are the most promising chemical elements - the candidates for production of thermo- and crack-resistant ceramics.

\section{Experimental}

The samples for investigation were prepared by hot isostatic pressing at the pressure of $30 \mathrm{MPa}$ at the temperature of $1350^{\circ} \mathrm{C}$ of a mixture of ultradisperse powders $(1-10 \mu \mathrm{m})$ of titanium carbide (TiC) and aluminum (Al) with a different molar ratio of components. The holding time under pressure at this temperature during the preparation of the samples was $\approx 30 \mathrm{~min}$. In some cases copper $(\mathrm{Cu})$ or tin $(\mathrm{Sn})$ was used as an additive to the main MAX phase in an amount of $\approx(1-3)$ wt. $\%$.

The phase composition of the samples was monitored by X-ray analysis.
The microhardness and fracture toughness test was carried out with the Vickers indenter on the PMT-3 microhardness meter by varying of the load magnitude and of the exposure time under load. The dimensions of the prints and the dimensions of the radial cracks propagating from the corners of the indentation were measured using a metallographic microscope MIM-10.

The data obtained were used to calculate the microhardness $\left(H_{v}\right)$ and fracture toughness $(K)$ by formulas: $H_{v} \approx 0,189 P / d^{2}$, $\left.K \approx 7.4 \cdot 10^{-2} P / c\right)^{3 / 2}$, where $P$ is the load on the indenter, $d$ is the length of the diagonal of the residual indentator print, $c$ is the mean length of the radial cracks, measured from the center of the print.

The structure of the investigated samples was studied both on thin sections and on faults using optical and scanning electron microscopy.

The results of all our experiments are shown in Fig. 1-3 and in Table.

\section{Results and discussion}

Fig. 1a, b shows the imprints of the Vickers indentor at various loads. At the load of $P \approx 7,35 \mathrm{~N}$, the microcrack formation was observed from the corners of the imprint (Fig. 1b). Based on the measurement of the parameters $d$ and $c$, the microhardness $H_{v}$ and the crack resistance $K$ of the samples were calculated. The results are shown in Table. In accordance with the accepted designations, $H_{v} 0.02 / 10$ - microhardness of the sample under load of $0.02 \mathrm{~kg}$ at the time of exposure under load $10 \mathrm{c}$.

Fig. 2 shows the structure of the material under study. 


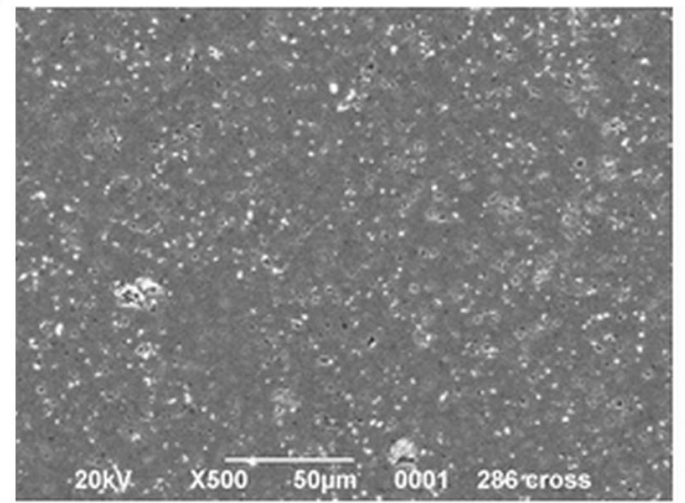

a)

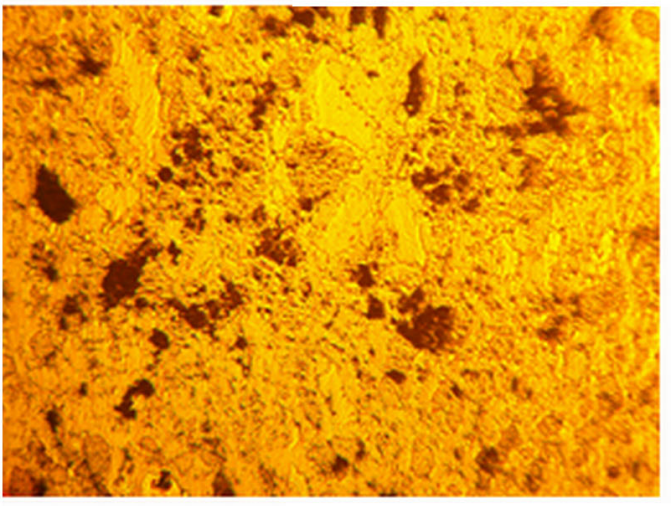

c)

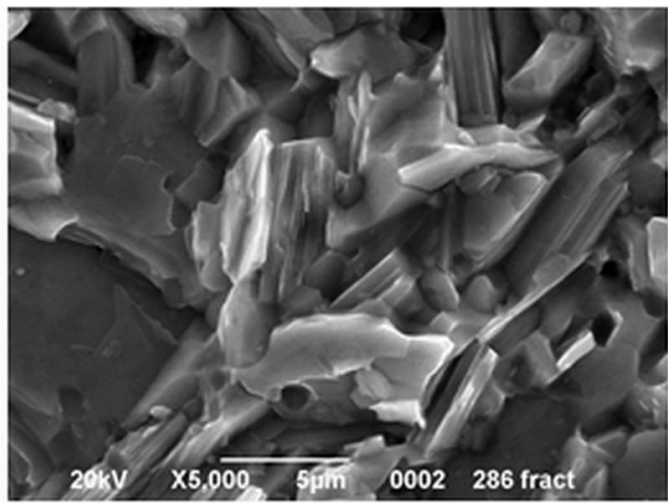

b)

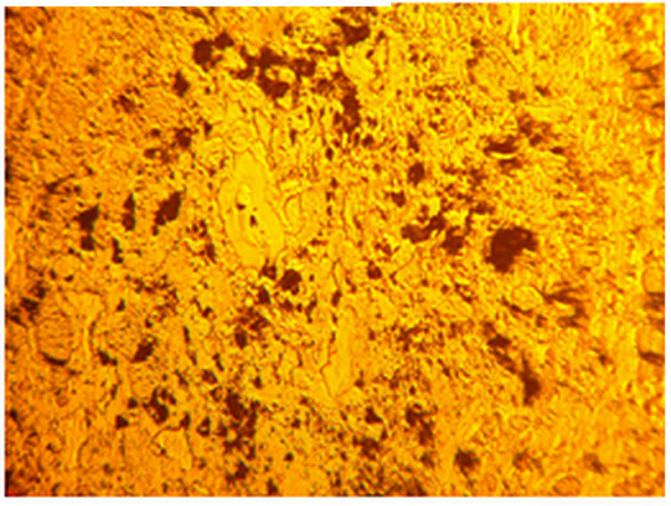

d)

$400 \mu \mathrm{m}$

Fig. 2. Typical structure of MAX phases: a - SEM sample section image, $b$ - SEM image of the sample fracture, c,d - optical images of the sample section.

The X-ray diffraction data of the samples are shown in Fig. 3 Analysis of the obtained diffractograms indicates the formation of at least three phases: $\mathrm{TiC}, \mathrm{Ti}_{2} \mathrm{AlC}$ and $T_{3} A I C_{2}$. A characteristic feature is the absence of a crystalline phase (Ti-Al), for example, of an intermetallic compound $\mathrm{Al}_{3} \mathrm{Ti}$, which agrees with the assumption expressed in paragraph 3.

The obtained experimental data will be discussed in the framework of the proposed concept: the unique physical properties of materials based on MAX phases are due to the different nature of chemical bonding forces acting between heterogeneous atoms, as well as to the specific structural state formed in the process of compaction (sintering) of ceramics at high temperature under pressure.

The results of the study are well explained as follows. The thermal stability of the ceramic material under study $(1000-$ $1100^{\circ} \mathrm{C}$ ) is provided by the presence of a refractory phase $\mathrm{TiC}$.

The microhardness of the samples is essentially non-uniform and, depending on the structural state of the surface, varies in the
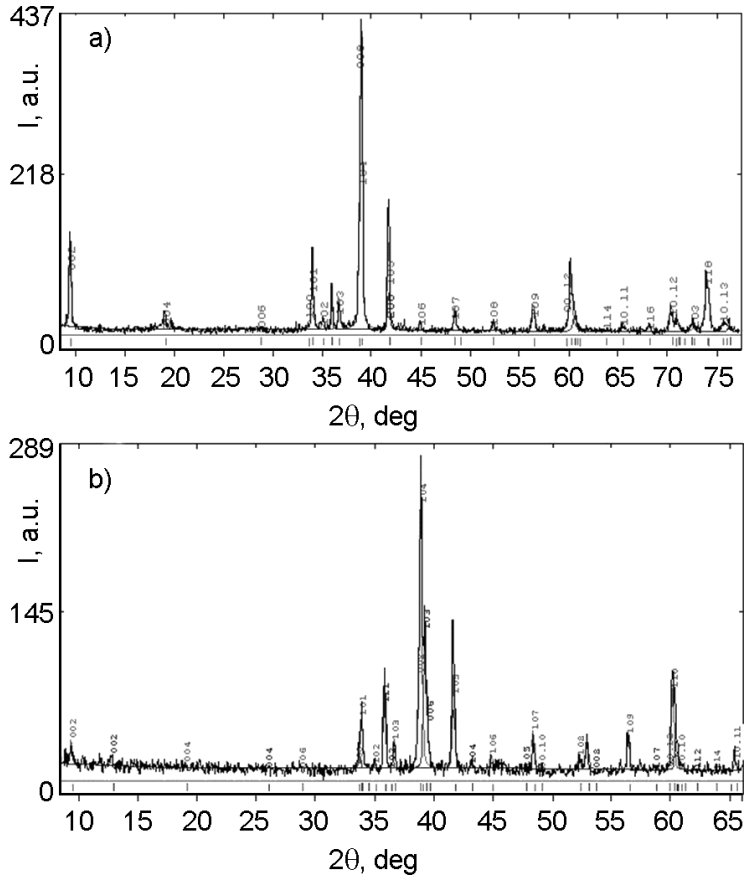

Fig. 3. Diffractograms of the investigated MAX-phase samples: a $-\mathrm{Ti}_{3} \mathrm{AlC}_{2} 89$ wt. \%, TiC 11 wt. $\%$, b $-\mathrm{Ti}_{3} \mathrm{AlC}_{2} 61$ wt. $\%, \mathrm{TiC}$ 17 wt. $\%, \mathrm{Ti}_{2} \mathrm{AlC} 22$ wt. $\%$. 
Table 1. Values of microhardness $H_{v}$ and crack resistance $K$ of different samples.

\begin{tabular}{|c|c|c|c|c|c|c|c|}
\hline Sample & $\begin{array}{c}H_{V} \\
0,02 / 10, \\
\mathrm{MPa}\end{array}$ & $\begin{array}{c}H_{V} \\
0,02 / 30, \\
\mathrm{MPa}\end{array}$ & $\begin{array}{c}H_{V} \\
0,1 / 10 \\
\mathrm{MPa}\end{array}$ & $\begin{array}{c}H_{V} \\
0,1 / 30 \\
\mathrm{MPa}\end{array}$ & $\begin{array}{c}H_{V} \\
0,1 / 300, \\
\mathrm{MPa}\end{array}$ & $\begin{array}{c}H_{V} 0,4- \\
0,9 / 30, \\
\mathrm{MPa}\end{array}$ & $\begin{array}{c}K, \\
\text { MPa.m }^{1 / 2} \\
\text { load } \\
7.35 \mathrm{H}\end{array}$ \\
\hline $\begin{array}{c}\mathrm{Ti}_{3} \mathrm{AlC}_{2} 89 \%, \mathrm{TiC} 11 \% \\
\mathrm{Ti}_{3} \mathrm{AIC}_{2} 61 \%, \mathrm{TiC} 17 \%, \mathrm{Ti}_{2} \mathrm{AlC}_{2} 22 \% \\
\mathrm{Ti}_{3} \mathrm{AlC}_{2} 93 \%, \mathrm{TiC} 4 \%, \mathrm{Al}_{2} \mathrm{O}_{3} 3 \% \\
\mathrm{Ti}_{3} \mathrm{AlC}_{2}\end{array}$ & 429 & 395 & $\begin{array}{c}698 \\
1000 \\
665\end{array}$ & $\begin{array}{l}513 \\
620 \\
908 \\
536\end{array}$ & $\begin{array}{l}524 \\
880 \\
470\end{array}$ & 455 & 7,4 \\
\hline
\end{tabular}

range of $H_{v} \approx(0,4-1) \mathrm{GPa}$, which indicates the heterogeneity of the structure.

The fracture toughness of the test material reaches the value $K \approx 7,4 \mathrm{MPa} \cdot \mathrm{m}^{1 / 2}$. Such a high value of crack resistance is naturally to associate with the fact that a specific layered structure is formed in the investigated material: the grains of the refractory crystalline phases are separated by thin phase (TiAl) layers, which are characterized by an unordered arrangement of atoms, which is confirmed by X-ray studies (see Fig. 3). These layers prevent the propagation of germinal microcracks in the transition from one crystalline grain to another (neighboring) grain, and thereby ensure a high crack resistance of the test material.

\section{Conclusion}

The studied material is characterized by increased thermal and crack resistance. These properties are due to the special physicochemical nature of the binding forces between the elements of the emerging phases and to the specific structural state charac- terized by the presence of thin interlayers with an unordered arrangement of atoms.

The authors are grateful to P.V.Mateychenko for electron microscopic images of the structure of the samples studied in this work.

\section{References}

1. W.Barsoum, Prog. Solid St.Chem., 28, 201 (2000).

2. T.A.Prikhna, A.V.Starostina, D.Litzkendorf et al., Sverkhtverdye Materialy, No. 1, 14 (2014).

3. M.A.Hadi, R.V.Vovk, A.Chroneos, J.Mater. Scie.:Mater. Electron., 27, 11925 (2016).

4. M.A.Hadi, M.Roknuzzaman, A.Chroneos et al., Comput. Mater. Sci., 137, 318 (2017).

5. M.P.Slavinskij, Fiziko-himicheskie Svojstva Elementov, Metallurgizdat, Moscow (1952) [in Russian].

6. I.N.Frantcevich, Poroshkovaya Metallurgiya, Naukova Dumka, Kiev (1977),

7. Yu.I.Boyko, Visnik KhNU, seriya Fizika, 15, 54 (2011).

8. V.M.Finkel, Fizika Razrusheniya, Metallurgiya, Moscow (1970) [in Russian]. 